$$
\text { DOE ID } / 13266 \ldots \text { TH }
$$

\title{
Final PHP Bench-Scale Report for the DOE-ID/SAIC Sole Source Contract
}

April 1997

Science Applications International Corporation

Waste Management Technology Division

545 Shoup Avenue

Idaho Falls, Idaho 83402-3575

Prepared for:

U.S. Department of Energy Idaho Operations Office Idaho Falls, ID 83402 


\section{DISCLAMMER}

Portions of this document may be illegible in electronic image products. Images are produced from the best available original document. 


\section{CONTENTS}

1. PHP PROJECT DESCRIPTION $\ldots \ldots \ldots \ldots \ldots \ldots \ldots \ldots \ldots \ldots \ldots \ldots$

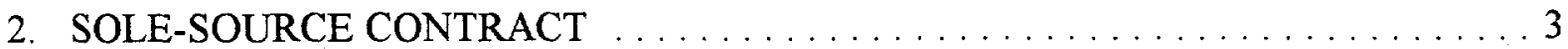

3. BENCH-SCALE SYSTEM ACCOMPLISHMENTS $\ldots \ldots \ldots \ldots \ldots \ldots \ldots \ldots$

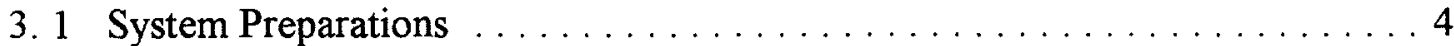

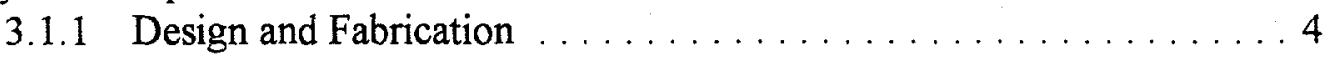

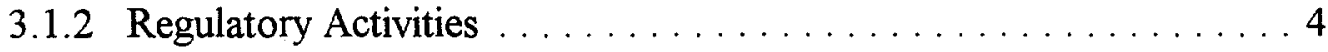

3.1 .3 Stakeholder Interfaces . . . . . . . . . . . . . . . . . . . 6

3.1 .4 Planning Documents $\ldots \ldots \ldots \ldots \ldots \ldots$

3.1 .5 Installation . . . . . . . . . . . . . . . . . . . 9

3.1 .6 STAR Center Support $\ldots \ldots \ldots \ldots \ldots \ldots \ldots \ldots$

3.1 .7 Training . . . . . . . . . . . . . . . . . . . 9

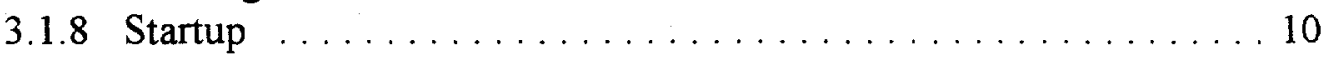

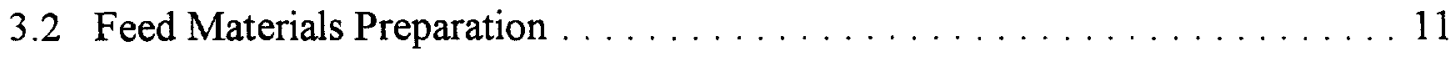

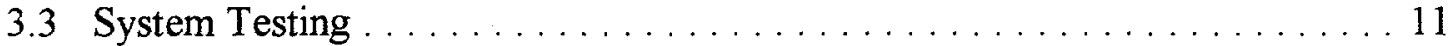

3.3 .1 Testing Performed to Date . . . . . . . . . . . . . . . 11

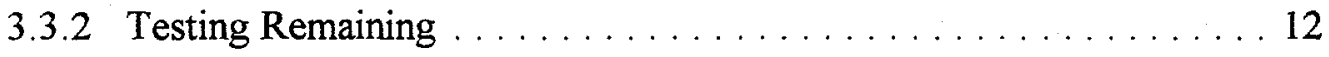

4. TECHNOLOGY TRANSFER ACTIVITIES $\ldots \ldots \ldots \ldots \ldots \ldots \ldots \ldots \ldots$

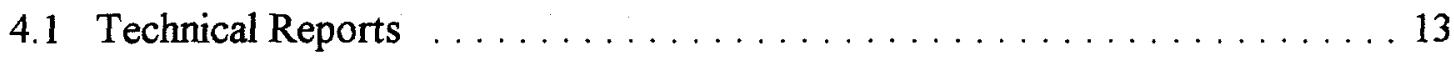

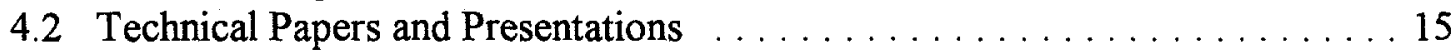

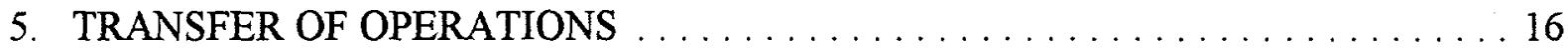

FIGURES

Figure 1. Activities of the PHP Technology Development Project. 


\section{PHP PROJECT DESCRIPTION}

The Plasma Hearth Process (PHP) Technology Development Project was established to develop, test, and evaluate a new concept for treating mixed waste. The new concept uses direct current $(\mathrm{dc})$ transferred-arc plasma torch technology to process mixed waste into a glass-like end-product. Under the cognizance of the U.S. Department of Energy (DOE) Office of Technology Development (OTD) Mixed Waste Focus Area (MWFA), the technology is being explored for its potential to treat mixed waste. Because it is a mature technology, well-understood and commercially available, it is expected to develop rapidly in this new application. This report summarizes the radioactive bench-scale system activities funded under PHP Sole Source Contract DE-AC07-94D13266 through the end of the contract.

The project is being conducted primarily through the DOE-Idaho Operations Office (DOE-ID), in cooperation with the DOE-Chicago Operations Office (DOE-CH). The principal non-DOE organizations involved in the PHP project are Science Applications International Corporation (SAIC), Retech, Argonne National Laboratory-West (ANL-W), and Lockheed Idaho Technologies Company (LITCO). SAIC is the technology developer and technical lead for the project. Retech supplies the plasma torch equipment and melter chambers and is providing the facility to house the nonradioactive demonstration. ANL-W is responsible for preparing the facility to house the radioactive demonstration and for managing the facility during installation, qualification, and testing. LITCO provides hardware procurement, technical review, and manages a contract to SAIC for pilot-scale work.

The PHP project entails several related activities, illustrated in Figure 1. One is the design, fabrication, and testing of a bench-scale PHP system that will be used to demonstrate the treatment of radioactive materials, the subject of this report. Activities related to the bench-scale system will be paralleled by the development of a pilot-scale system. This system, very near full-scale in proportion, will be used to develop the system hardware, using nonradioactive surrogate waste, and will verify the technology's readiness for full production application.

The PHP has the potential in a wide range of applications to vitrify a wide variety of mixed wastes stored at sites throughout the DOE complex. The features that make the PHP particularly attractive include:

- The ability of the process chamber to accept whole drums of waste;

- Little or no front-end handling, feed preparation, or pretreatment;

- Reduced waste characterization requirements;

- The ability to destroy organic compounds, including hazardous organics;

- A stable, nonleaching end-product that complies fully with all RCRA regulations. 


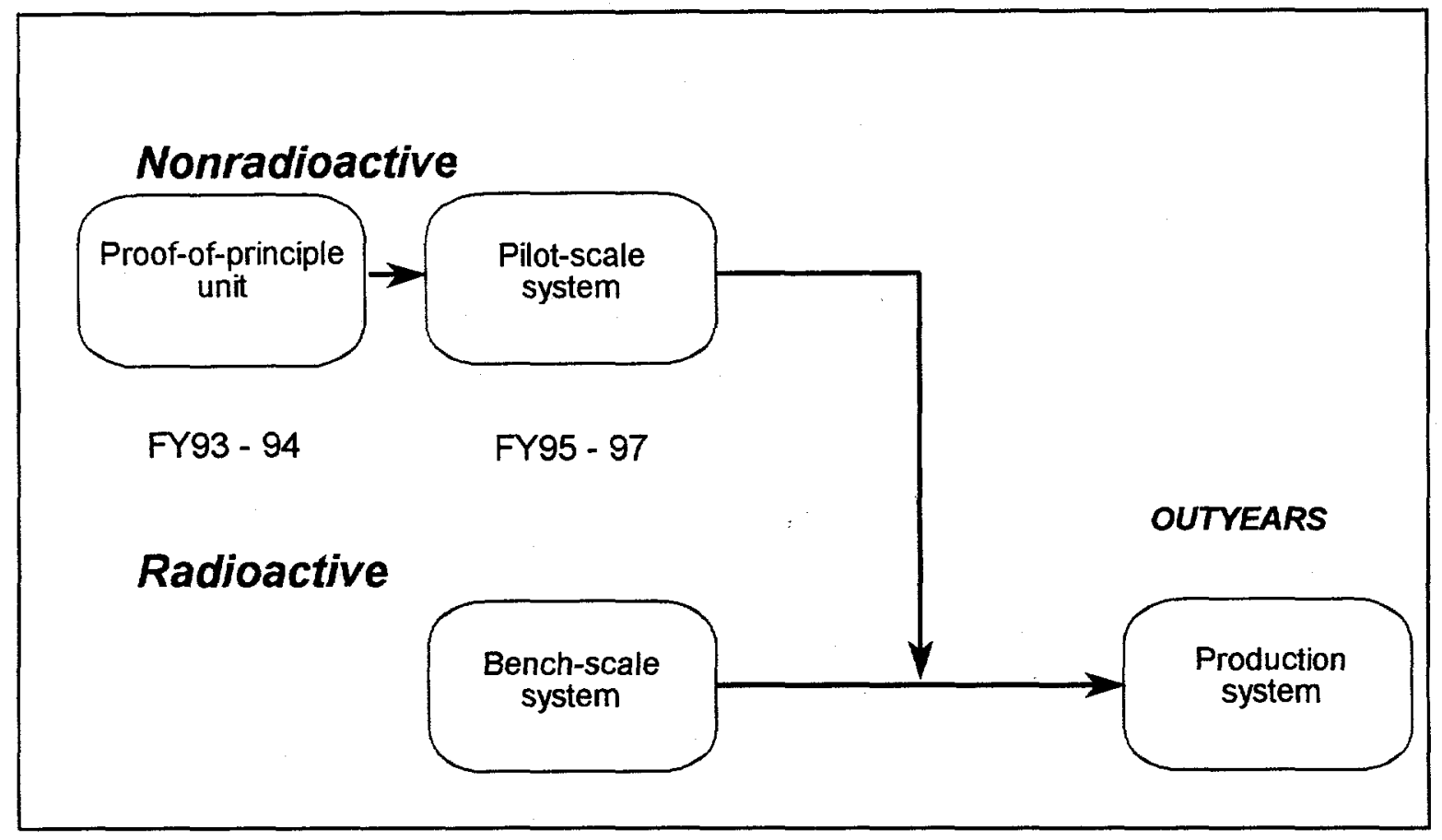

Figure 1. Activities of the PHP Technology Development Project. 


\section{SOLE-SOURCE CONTRACT}

The PHP concept was proposed by SAIC to the DOE's Office of Technology Development in FY90 as an unsolicited proposal for development of a technology to address stored TRU waste compacted at the Rocky Flats Plant. DOE funding in the early years was provided through a variety of Field Offices and their respective M\&O contractors. Based on this early development work, DOE-ID prepared a sole source justification in FY94 for providing a comprehensive R\&D contract to SAIC for radioactive system demonstrations at the INEL. The contract was awarded in FY95. The original scope of the subject contract proposed by DOE-ID included procuring the radioactive melter systems (i.e. bench- and field-scale) as well as all technical development work. Prior to contract award, this scope was revised to exclude procurement of the bench-scale and field-scale melter and offgas hardware but would still cover contracted design work to design the melter and offgas systems as well as all technical development work. At that time it was acknowledged by technical and contracting officers that this decision might need to be revisited in the future, depending on Project developments.

During workup of the melter procurement subcontract, it was decided by the Project that detailed melter design as well as procurement costs would be provided for in the LITCO/Retech subcontract. There was a subsequent delay in the LITCO melter procurement subcontract cycle, with approximately six months lost in the Project schedule, and the Project felt it best that Retech not be asked to procure or fabricate the offgas systems so that they could concentrate on timely delivery of the melters. SAIC, which was going to design the offgas systems anyway, was then given responsibility for procurement and fabrication of them also.

Since delivery, installation, and startup of the bench-scale melter system, efforts under this contract have been limited to operating the process system, providing technical support to ANL-W, and collecting and analyzing offgas system samples. In late FY96, the Mixed Waste Focus Area decided to divert all funding for the remaining bench-scale project to ANL-W for FY97. Work conducted by SAIC in FY97 under the Sole-Source contract was performed utilizing FY96 funds carried over into FY97. 


\section{BENCH-SCALE SYSTEM ACCOMPLISHMENTS}

\section{1 System Preparations}

\subsubsection{Design and Fabrication}

The radioactive bench-scale PHP system was designed and constructed to test and evaluate the treatment of surrogate and actual radioactive mixed waste. Located at the Transient Reactor Test (TREAT) facility of ANL-W at the Idaho National Engineering Laboratory (INEL), the radioactive bench-scale system is configured to model the conditions of the near-full-scale nonradioactive pilot-scale PHP system being tested at the Retech facility in Ukiah, California. The bench-scale tests are investigating, in a cost-effective manner, the issues related to treating radioactive materials before activities proceed to a more expensive full-scale radioactive demonstration.

Design of the bench-scale system was completed in FY95, culminating in a formal Title II design review of the melter system. System component fabrication began in FY95 and was completed in early FY96. The bench-scale melter and associated subsystems were fabricated under a LITCO contract by Retech at its Ukiah, California, facility. The melter and support subsystems were delivered to ANL-W in February, 1996 for installation and connection to the remainder of the process system.

The remainder of the system, from the secondary combustion chamber (SCC) through the air pollution control system (APCS), was procured in FY95 and assembled and checked out by SAIC at its Science and Technology Applications Research (STAR) Center facility in Idaho Falls in early FY96. These system components were delivered to ANL-W in December 1995, for installation, checkout, and demonstration.

Documents and procedures that directly support operation of the PHP experiment support systems were prepared and finalized. These included feed materials preparation procedures, equipment operating instructions, maintenance instructions, and test procedures. Process and support system acceptance tests were conducted for all system components based on formal acceptance test procedures. A series of integrated system acceptance tests, or system operational tests, were then performed and demonstrated that integrated system operations met design criteria.

\subsubsection{Regulatory Activities}

The regulatory permits/documents necessary for the PHP radioactive bench-scale system include:

- A permit to construct (PTC) and prevention of significant deterioration (PSD) review under Idaho state air regulations, 
- National Emission Standards for Hazardous Air Pollutants (NESHAPs) application/approval,

- A National Environmental Policy Act (NEPA) categorical exclusion approval,

- A RCRA Treatability Study Notice for planned actual waste tests.

All regulatory documents and permits are completed and in place. The status of the bench-scale regulatory activities is summarized in the following sections.

\section{$\underline{\text { PTC/PSD }}$}

The PTC application was submitted to the state of Idaho on April 30, 1994. The state issued a Permit to Construct in February of 1996 allowing the project to pursue construction and operations. The state is in the process of making changes to the permit to bring it up to date with system changes previously submitted, including the substitution of a HEPA filter for the baghouse. The permit will be reissued once the changes are made, but the changes do not impact ongoing project activities.

\section{NESHAPS}

The bench-scale NESHAPs application was submitted to the U.S. Environmental Protection Agency (EPA), Region 10, on April 30, 1994, and approved by it in a letter dated May 10, 1994.

\section{NEPA}

ANL-W submitted the bench-scale environmental checklist to DOE-CH, which determined, in a letter dated September 1, 1994, that the project met the requirements of a categorical exclusion under NEPA Regulation, 10 CFR Part 1021.400, Subpart D. This approval completed the NEPA review process necessary to conduct the bench-scale activities.

\section{$\underline{\text { RCRA }}$}

The EPA requires a 45-day notice be submitted before testing of actual waste begins under a treatability exemption. The state of Idaho requested an additional description of the bench-scale project be provided prior to the 45 -day notice. The description was prepared, and DOE-CH presented it to the state of Idaho on September 9, 1994. The 45-day notice requirement has subsequently been covered under the INEL's annual overall treatability study notice to the state. 


\subsubsection{Stakeholder Interfaces}

Throughout the term of the contract, PHP project participants continued periodic meetings and presentations with stakeholders interested in mixed waste treatment technologies, DOE programs, the INEL, or related programs or facilities.

\begin{tabular}{|c|c|c|}
\hline $\begin{array}{l}1993 \\
\text { October }\end{array}$ & San Francisco, CA & Western Governors Association \\
\hline November & Washington, D.C. & $\begin{array}{l}\text { DOE (EM-30, EM-50), Mixed Waste Treatment } \\
\text { Technology displays }\end{array}$ \\
\hline December & $\begin{array}{l}\text { Idaho Falls, ID } \\
\text { Idaho Falls, ID }\end{array}$ & $\begin{array}{l}\text { DOE (EM-50), program review with Paul Hart } \\
\text { State of Idaho RCRA permitting personnel }\end{array}$ \\
\hline $\begin{array}{l}1994 \\
\text { January }\end{array}$ & Washington, D.C. & $\begin{array}{l}\text { Develop Onsite Innovative Technologies (DOIT) } \\
\text { Committee }\end{array}$ \\
\hline February & $\begin{array}{l}\text { Idaho Falls, ID } \\
\text { Idaho Falls, ID } \\
\text { Idaho Falls, ID }\end{array}$ & $\begin{array}{l}\text { State of Idaho RCRA permitting personnel and } \\
\text { INEL Oversight Office } \\
\text { EG\&G EM-30 projects representatives } \\
\text { EM-321 }\end{array}$ \\
\hline April & $\begin{array}{l}\text { Idaho Falls, ID } \\
\text { Idaho Falls, ID } \\
\text { Washington, D.C. } \\
\text { Phoenix, AZ }\end{array}$ & $\begin{array}{l}\text { EM-50 (JoAnn Bassi) } \\
\text { Shoshone-Bannock Tribal representatives } \\
\text { MWIP Midyear Review } \\
\text { Weapons Complex Monitor Colloquium }\end{array}$ \\
\hline May & Idaho Falls, ID & Rocky Flats Waste Treatment Project personnel \\
\hline July & $\begin{array}{l}\text { Idaho Falls, ID } \\
\text { Idaho Falls, ID }\end{array}$ & $\begin{array}{l}\text { Western Governors Association (WGA) } \\
\text { Demonstration Site Implementation Team (DSIT) } \\
\text { State of Idaho RCRA permitting personnel }\end{array}$ \\
\hline August & Idaho Falls, ID & DOE (EM-50) with Paul Hart \\
\hline December & Idaho Falls, ID & WGA DSIT meeting \\
\hline
\end{tabular}


Idaho Falls, ID

Salt Lake City, UT

February Pocatello, D

Idaho Falls, ID

Boise, ID

Fort Hall, ID

March Washington, D.C.

April

May

Reno, NV

Idaho Falls, ID

July

August Idaho Falls, ID

October

Idaho Falls, Idaho

November Idaho Falls, ID

Idaho Falls, ID

December Idaho Falls, ID

1996

January

Idaho Falls, ID

April

Idaho Falls, ID
INEL DSIT meeting

National Technical Workgroup

Radiological and Hazardous Material

Measurement Systems open house at Idaho State University

Meeting with officials of Senator Craig's and Representative Crapo's offices

INEL/White House Conference Workshop

INEL DSIT meeting

MWFA staff briefing

INEL DSIT meeting

WGA DOIT Mixed Waste Working Group meeting

Tribal and Public Forum on Technology

Acceptance

WGA DSIT meeting

MWFA poster session at the Senate Hart Office Building

Representatives from DOE-ID Waste

Management (EM-30) office toured STAR Center

NNEL DSIT meeting

Open House for the assembled bench-scale air pollution control system at the SAIC STAR

Center

INEL DSIT meeting

WGA DOIT Committee meeting

At the request of the Mixed Waste Focus Area, a group of scientists from Russia toured the STAR Center

NNEL DSIT meeting 
May

Idaho Falls, ID

Idaho Falls, ID

September Idaho Falls, ID

October
Salt Lake City, UT
A group of nuclear scientists from France toured the bench-scale system at ANL-W

A group from the Amarillo Center for Plutonium Studies toured the bench-scale system at ANL-W

Community Leaders Network, a stakeholder group formed by DOE, toured the bench-scale facility

Project managers attended and made a presentation on the PHP to the MWFA's FY96 Wrap-up and FY97 Kickoff Meeting

\subsubsection{Planning Documents}

Through each phase of the project, SAIC personnel documented the planning required to see the PHP project to its completion. The list of planning documents includes the following:

- Conceptual Design Report for the Plasma Hearth Process Bench-Scale Radioactive System

- Feed Material Handling and Waste Disposition Plan for the Radioactive Bench-Scale Plasma Hearth Process System

- Project Plan for the Radioactive Plasma Hearth Process Demonstration Project

- Proposed Regulatory Strategy for Development of the Plasma Hearth Process for the Department of Energy

- Quality Assurance Project Plan for the Radioactive Plasma Hearth Process Demonstration Project

- SAIC Plasma Hearth Process Demonstration at the Argonne National Laboratory-West TREAT Facility: Preliminary Safety Assessment Report

- SAIC Training and Access Requirements Plan for the Plasma Hearth Process Radioactive Bench-Scale System

- Sampling and Analysis Plan for the Plasma Hearth Process Radioactive Bench-Scale System

- System Design Description for the Plasma Hearth Process Radioactive Bench-Scale System Process Equipment

- Test Plan for Radioactive Testing of the Bench-Scale Plasma Hearth Process

- Waste Acceptance Criteria/Guidance for the Radioactive Bench-Scale Plasma Hearth Process 


\subsubsection{Installation}

ANL-W was responsible for preparation of the test facility for installation of the PHP process equipment and providing engineered supporting systems that enable the PHP experiments to be operated safely and effectively to accomplish the program's testing and evaluation mission. SAIC provided technical support and review of all support system and installation designs. These support systems provide radiological confinement, communications, radiological monitoring/alarming, utilities, fire protection, contaminated-materials handling, process sampling, and preparation of the radioactive feed materials. In addition, ANL-W provides state-of-art laboratory analyses and innovative, noninvasive offgas monitoring instrumentation.

\subsubsection{STAR Center Support}

Through the conclusion of FY96, thirty-five tests have been were conducted at the Science and Technology Applications Research (STAR) Center by SAIC, under contract to DOE-ID. Of these tests, ten were specific to the radioactive bench-scale system. The details and results of these tests were published in "Results of STAR Center Testing in Support of the Radioactive Bench-Scale Plasma Hearth Process System," C. Cornelison (SAIC-96/1018). A major focus of this testing was training of operators for the bench-scale system at TREAT. In addition, crucible materials and methods of construction were examined. The existing RBS crucible/hearth design and method of construction resulted from this work. Also, several treatability studies of potentially problematic waste feeds were examined.

Twenty-five tests were conducted that focused on PHP technology in general. These test results are detailed in "Results of STAR Center Testing in Support of the Plasma Hearth Process," C. Cornelison, G. L. Leatherman, R. Woodvine, and J. D. Atkinson, (SAIC-96/1017). These tests focused on a variety of technical issues, including: processability of potentially difficult-to-treat waste streams, processability of secondary waste streams, testing of PHP system design models, refractory performance, training, and casualty simulations. Significant contributions were made in examining water-leak scenarios onto the molten pool. Simulated torch failure modes showed that under realistic failure modes that the system would maintain negative pressure. Promising results were found in treating actual flyash from previous PHP testing programs. The resulting slag showed high partitioning values for metals of interest (surrogate radionuclides and RCRA metals). In addition, the processability of potentially problematic waste streams such as used HEPA filters, leaded rubber gloves, heterogeneous debris was found to be quite good.

\subsubsection{Training}

All personnel who assembled the bench-scale equipment or operated the installed system received an extensive series of training that met ANL-W site requirements and exceeded 
standards set by the Occupational Safety and Health Administration. As appropriate to the individual, that training included:

- 24- or 40-hr hazardous waste site operations and emergency response

(HAZWOPER) training, with annual 8-hr refresher courses;

- 8-hr HAZWOPER Supervisor training;

- Respirator training and qualification;

- Classroom instruction for PHP system operations;

- A minimum of 20 hours of hands-on console training at an operating PHP system;

- ANL-W TREAT facility training and qualification;

- Radiation Worker II training;

- Classroom and hands-on instruction specific to offgas sampling, for offgas samplers;

- Demonstration of hands-on familiarity with all process and support systems including a comprehensive walk-down of each system with the system expert.

- Written exams on the operating instructions and operating procedures for all PHP process and support systems.

- Sign-off on required reading of the documents:

- Conduct of Operations Requirements for DOE Facilities (DOE 5480.19),

- Feed Material Handling and Waste Disposition Plan for the Radioactive Bench-Scale Plasma Hearth Process System,

- Sampling and Analysis Plan for the Plasma Hearth Process Radioactive Bench-Scale System

- Test Plan for Radioactive Testing of the Bench-Scale Plasma Hearth Process

\subsubsection{Startup}

In late-1995/early-1996, the bench-scale air pollution control system was assembled, tested, and adjusted at the STAR Center to check the system's operability before engineers moved it to the ANL-W TREAT facility for reassembly. The equipment tested included the full quench/packed-bed scrubber, the evaporative cooler, the secondary combustion chamber, and the complete air pollution control system. Project personnel were satisfied with the equipment's performance and transferred it to the TREAT facility for installation with the melter system procured by LITCO.

Following installation of the complete process system in ANL-W, a comprehensive series of startup tests were performed to ensure the system was ready for the surrogate waste processing demonstration. Individual system acceptance tests were performed followed by an integrated system acceptance test. The system was then operated on nonhazardous materials to further train the operators and to evaluate system performance prior to proceeding with demonstrations on surrogate waste test recipes. 


\subsection{Feed Materials Preparation}

The surrogate wastes to be processed in the bench-scale system were selected based on simulating a large cross-section of the waste types currently stored at the INEL and at other DOE facilities. The waste categories selected include:

- Combustibles,

- Organic sludges,

- Inorganic sludges,

- Heterogeneous wastes (mixed paper, metal, glass, etc).

Surrogate material recipes for simulating the INEL mixed wastes in the surrogate and spiked-radionuclide tests were updated and are documented in "Feed Material Handling and Waste Disposition Plan for the Radioactive Bench-Scale Plasma Hearth Process system" (SAIC-94/1159), which was reissued in FY96. Radioactive spike sources have been specified and obtained and include plutonium, uranium, and cesium. The surrogate waste for the base runs on inorganic sludges, combustibles, and heterogeneous debris were prepared and delivered to ANL-W and tests conducted on each. Materials for organic sludges were obtained, but the preparation of the recipe has not been requested.

The MWFA directed the project to discontinue the identification of, and efforts to obtain, actual mixed wastes to treat in the bench-scale melter and to concentrate on surrogate and spike-radionuclide tests in FY97. The Focus Area also directed the project to coordinate test activities with the Pacific Northwest National Laboratory's (PNNL) dc Arc Melter program to jointly address waste treatment issues identified by the MWFA. Four recipes for sludges, varying certain constituents parametrically, have been specified. Two of the recipes, containing primarily inorganic constituents, were prepared and delivered to ANL-W. The materials for the remaining two sludge recipes, containing one or more organic constituents, are on hand and will be prepared just prior to testing.

\subsection{System Testing}

\subsubsection{Testing Performed to Date}

To date the Bench-Scale Project has conducted four successful surrogate waste tests containing hazardous materials and/or radionuclide surrogates, in addition to two integrated system tests on a nonhazardous version of the inorganic sludge waste recipe. Integrated system test T-IS-1 served to provide a processing blank to identify elemental impurities inherent to the system and the sludge base components. Experiment N-IS-1 contained the base surrogate inorganic sludge from T-IS- 1 as well as cerium $(\mathrm{Ce})$ as a surrogate for plutonium and a stable isotope of cesium (Cs). Experiment N-IS-1A was a repeat of N-IS-1, but included the RCRA heavy metals barium $(\mathrm{Ba})$, beryllium $(\mathrm{Be})$, cadmium $(\mathrm{Cd})$, chromium $(\mathrm{Cr})$, mercury $(\mathrm{Hg})$, nickel $(\mathrm{Ni})$, and lead $(\mathrm{Pb})$. Experiment $\mathrm{N}-\mathrm{HD}-1$ processed a surrogate heterogeneous debris waste recipe that contained RCRA heavy metals silver (Ag), arsenic 
(As), $\mathrm{Ba}, \mathrm{Hg}, \mathrm{Pb}$, and selenium ( $\mathrm{Se}$ ), as well as $\mathrm{Ce}$ and $\mathrm{Cs}$, plus "anomalous" debris consisting of small blocks of graphite, wood, and fire brick. Experiment N-CD-1 processed a surrogate combustible debris waste recipe that contained RCRA heavy metals $\mathrm{Ag}, \mathrm{As}, \mathrm{Ba}, \mathrm{Hg}$, and $\mathrm{Se}$, as well as $\mathrm{Ce}$ and $\mathrm{Cs}$, plus the hazardous organic liquid carbon tetrachloride $\left(\mathrm{CCl}_{4}\right)$.

\subsubsection{Testing Remaining}

Planning is in progress for all tests subsequent to those reported in this document. SAIC is coordinating with ANL-W in this effort. Thus, ANL-W's current test plan (Test Plan for the Plasma Hearth Process Radioactive Bench-Scale System: FY-97 Program, ANL-W Document No. W0410-0174-AP-00) may be revised.

The thrust of the test planning effort must hinge on promoting successful development and implementation of the PHP as a waste treatment technology for DOE. The bench-scale system was designed and built to provide data to correlate with pilot-scale system testing. Bench-scale system data that are critical for interpretation of pilot-scale system test data consist of correlations between the partitioning of plutonium and uranium radionuclides to their designated surrogate, cerium. The partitioning factor of primary importance is transport to the process offgas (or conversely, retention in the slag). The partitioning correlations need to be established by triplicate testing on a minimum of three nominal waste types, yielding a minimum matrix of nine tests. The nominal waste types would include an inorganic sludge, an organic sludge, and a heterogeneous or combustible debris. Among each set of three tests, the following test parameters must be kept constant:

- starting materials (composition and quantity) in the hearth,

- feed composition,

- feed rate,

- stoichiometry (air flow to the primary chamber),

- energy density (torch power or primary chamber exit temperature).

These parameters will be kept constant during the corresponding pilot-scale tests. Therefore, it is imperative that these parameters be kept constant during the bench-scale tests in order for the bench-scale data to be scaled up and compared to the pilot-scale data. Furthermore, the bench-scale test schedule should be prioritized to produce these radionuclide/radionuclide surrogate correlations in time for their comparison with the results from parallel pilot-scale tests during FY97. 


\section{TECHNOLOGY TRANSFER ACTIVITIES}

\subsection{Technical Reports}

SAIC PHP personnel produced many papers and publications under this contract through FY96 and into FY97. They are listed, following.

1994

"Conceptual Design Report for the Plasma Hearth Process Bench-Scale Radioactive Waste System," SAIC-94/1003, S.D. Poling, L.M. DeWitt, Dr. G.L. Leatherman, S.M. Steele, W.P. Wolfe, A.L. Wollerman, March 1994.

"Plasma Hearth Process Technology Development Project Fiscal Year 1994 Year-End Report," SAIC-94/1141, Science Applications International Corporation, Waste Management Technology Division, November 1994.

"Proposed Regulatory Strategy for Development of the Plasma Hearth Process for the Department of Energy - Revision 1," SAIC-94/1112, A.L. Wollerman, July 1994.

"SAIC Plasma Hearth Process Demonstration at the ANL-W TREAT Facility: Preliminary Safety Analysis Report," SAIC-94/1002, S.M. Steele, February 1994.

1995

"Analysis of the Bench-Scale Plasma Hearth Process Imaging Systems," SAIC-95/1145,

N. Wittels, Dr. G.L. Leatherman, S.D. Poling, J.D. Atkinson, W.P. Wolfe, August 1995.

"Final Report for Advanced Analytical Instrumentation Demonstration," SAIC-95/1308,

C. Cornelison, L.M. DeWitt, G.R. Hassel, Dr. G.L. Leatherman, October 1995.

"Plasma Hearth Process Hardware Development," SAIC-96/1005, W.P. Wolfe, S.D. Poling, October 1995.

"Plasma Hearth Process Technology Development Project Fiscal Year 1995 Year-End

Report," PHP-95/001, Science Applications International Corporation, Waste

Treatment Technology Division, September 1995.

"Quality Assurance Project Plan for the Radioactive Plasma Hearth process Demonstration Project," SAIC-94/1111, L.M. DeWitt, February 1995.

"Sampling and Analysis Plan for the Plasma Hearth Process Radioactive Bench-Scale System," SAIC-95/1142, G.R. Hassel, L.J. Slate, May 1995.

"STAR Center Plasma Hearth Process Testing in Support of the Radioactive Bench-Scale Design," SAIC-95/1312, Dr. G.L. Leatherman, J.D. Atkinson, July 1995.

"STAR Center Test Plan to Support the Radioactive Bench-Scale Plasma Hearth Process

Demonstration," SAIC-95/1324, Dr. G.L. Leatherman, September 1995.

"Test Plan for Radioactive Testing of the Bench-Scale Plasma Hearth Process,"

SAIC-94/1014, Science Applications International Corporation, Waste Treatment

Technology Division, May 1995. 
“The Plasma Hearth Process," SAIC-95/1309, R.M. Geimer, L.M. DeWitt, December 1995.

"Waste Acceptance Criteria for the Plasma Hearth Process Radioactive Bench-Scale Testing," SAIC-94/1158, A.L. Wollerman, C. Cornelison, November 1995.

1996

"Evaluation of the Radioactive Bench-Scale Integrated System Operations Test Series," SAIC-96/1019, S.D. Poling, K.J. Rebish, September 1996.

"Feed Material Handling and Waste Disposition Plan for the Radioactive Bench-Scale

Plasma Hearth Process System," SAIC-94/1159, Science Applications International

Corporation, Waste Management Technology Division, August 1996.

"Plasma Hearth Process Technology Development Project Fiscal Year 1996 Year-End

Report," PHP-96/002, Science Applications International Corporation, Waste

Treatment Technology Division, September 1996.

"Project Plan for the Radioactive Plasma Hearth Process Demonstration Project,"

SAIC-96/1011, Science Applications International Corporation, Waste Management

Technology Division, June 1996.

"Radioactive Bench-Scale Plasma Hearth Process Spare Parts List," SAIC-96/1016,

L.J. Slate, September 1996.

"Results of STAR Center Testing in Support of the Plasma Hearth Process Fiscal Year 1996

Series I (11/6/95 to 1/18/96)," SAIC-96/1018, C. Cornelison, September 1996.

"Results of STAR Center Testing in Support of the Plasma Hearth Process Fiscal Year 1996

Series II, (3/26/96 to 8/2/96), SAIC-96/1017, C. Cornelison, Dr. G.L. Leatherman,

J.D. Atkinson, R.D. Woodvine, F. East, October 1996.

"Results of STAR Center Testing in Support of the Radioactive Bench-Scale Plasma Hearth

Process System - Rev. 1," SAIC-96/1003, C. Cornelison, L.M. DeWitt,

Dr G.L. Leatherman, March 1996.

"SAIC Training and Access Requirements Plan for the Plasma Hearth Process Radioactive

Bench-Scale System," SAIC-96/1006, T.L. Huebner, March 1996.

"System Design Description for the Plasma Hearth Process Radioactive Bench-Scale

System Process Equipment - Rev. 1," SAIC-94/1157, S.D. Poling, J. Conner,

J.M. Wilson, May 1996.

1997

"Initial Bench-Scale PHP Nonradioactive Phase Test Report," PHP-97/001, C. Cornelison, R.L. Gillins, G.R. Hassel, S.D. Poling, K. Rebish, April 1997. 


\subsection{Technical Papers and Presentations}

PHP personnel participated in a number of technical conferences and meetings to support technology transfer. Project staff presented PHP papers at:

1994

- 1994 Incineration Conference, Houston, Texas;

- 96th Annual Meeting of the American Ceramic Society, Indianapolis, Indiana;

- Executive Enterprises Conference on Mixed Waste, Seattle, Washington.

- 1995 International Incineration Conference, Bellevue, Washington;

- 1995 International Incineration Conference, Seattle, Washington;

- EPRI 1995 International Low-Level Waste Conference, Orlando, Florida;

- American Society of Mechanical Engineers Mixed Waste Symposium, Baltimore, Maryland;

- Annual meeting, American Ceramic Society, Cincinnati, Ohio;

- Emerging Technologies in Hazardous Waste Management VII Conference, American Chemical Society, Atlanta, Georgia;

- Fourth International Congress on Toxic Combustion Byproducts, Berkeley, California;

- Industrial and Engineering Chemistry Special Symposium, American Chemical Society, Atlanta, Georgia;

- International Symposium on Environmental Issues and Waste Management Technologies in the Ceramic and Nuclear Industries, Cincinnati, Ohio;

- International Symposium on Environmental Technologies: Plasma Systems and Applications, Atlanta, Georgia;

- Metatechnies '94 International Plasma Meeting, Bordeaux, France;

- Waste Management '95 Conference, Tucson, Arizona.

- 1996 International Incineration Conference, Savannah, Georgia;

- EPRI Vitrification of Low-Level Waste Conference, San Antonio, Texas;

- International Symposium on the Environmental Issues and Waste Management Technologies in the Ceramic and Nuclear Industries, Indianapolis, Indiana;

- Landfill and Mixed Waste Focus Area's TRU, MTRU, and MLLW Treatment Technologies Program/Technical Peer Review, Dallas, Texas;

- Spectrum '96, Seattle, Washington;

- Waste Management '96, Tucson, Arizona.

- Waste Management '97, Tucson, Arizona. 


\section{TRANSFER OF OPERATIONS}

In past years, ANL-W and SAIC tasks associated with the PHP Bench-Scale system were covered under separate Department of Energy Technical Task Plans (TTPs). However, the MWFA made a recent decision to reorganize the project structure, and in effect to turn the Bench-Scale Project over to ANL-W. ANL-W is now responsible for all Bench-Scale Project activities. SAIC support to the Bench-Scale Project in FY97 will be funded by carryover FY96 funds through the existing contract with DOE-ID until ANL-W can put a contract in place to cover SAIC participation. All subsequent SAIC work will be covered under this new ANL-W contract. 